\begin{tabular}{l|l|l} 
Jurnal Eksplorasi Akuntansi & $\begin{array}{l}\text { ISSN : 2656-3649 (Online) } \\
\text { Vol. 1, No 1, Seri B, Februari 2019, Hal. 109-122 }\end{array}$
\end{tabular}

\title{
AUDITOR STYLE DAN KOMPARABILITAS LAPORAN KEUANGAN
}

\author{
Riski Wulandari' ${ }^{1}$ Henri Agustin ${ }^{2}$, Mayar Afriyenti ${ }^{3}$ \\ 1) Alumni Jurusan Akuntansi Fakultas Ekonomi Universitas Negeri Padang \\ 2,3) Jurusan Akuntansi Fakultas Ekonomi Universitas Negeri Padang \\ *Korespondensi: riskiwulandari80@gmail.com
}

\begin{abstract}
Auditor style defined as a unique set of internal working rules for the interpretation and enforcement of accounting standard within the auditor's clienteles belongs to particular audit firm, especially Big 4 audit firms. As a consequence, financial statements of two companies audited by the same Big 4 auditor, subjected to the same audit style, tend to have comparable earnings which have a more similar accrual, than two companies audited by two different Big 4 auditors with different styles. This research attempts to examine the effect of this auditor style issue on manufacturing financial statement comparability listed in Indonesian Stock Exchange. For five years' observations, through 2012-2016 this research demonstrated a result with auditor style affects the comparability of reported earnings within a Big 4 auditor's clientele and found no effect of auditor style on financial statement comparability within a non-Big 4 auditor's clientele.
\end{abstract}

Keywords: Auditor's style, Big 4 auditor firm, financial statement comparability.

How to cite (APA $6^{\text {th }}$ style)

Wulandari, R, Agustin, H. \& Afriyenti, M. (2019). Auditor Style dan Komparabilitas Laporan Keuangan. Jurnal Eksplorasi Akuntansi, 1(1) Seri B, 109-122.

\section{PENDAHULUAN}

Komparabilitas (comparability) atau keterbandingan merupakan sebuah karakteristik dasar yang dapat meningkatkan kebermanfaatan laporan keuangan. Komparabilitas memungkinkan pengguna laporan keuangan mengidentifikasi perbedaan dan persamaan kinerja keuangan dua perusahaan. (FASB, 2008; IASB, 2008). Ikatan Akuntan Indonesia (IAI) menyatakan bahwa komparabilitas sangat diperlukan dalam meningkatkan kemampuan pengguna laporan keuangan untuk mengidentifikasi kecenderungan posisi keuangan dan menilai perubahan posisi keuangan.

Sebagai salah satu karakteristik kualitatif laporan keuangan, komparabilitas meraup perhatian yang cukup tinggi dari para regulator yang menjadikannya salah satu alasan kuat dalam proses penyempurnaan standar akuntansi yang ada (Lang et al., 2010). Di mana IASBInternational Accounting Standards Board telah membuat suatu standar pelaporan akuntansi internasional yaitu IFRS-Internatioanl Financial Reporting Standard. Standar ini dimaksudkan agar pelaporan akuntansi di berbagai negara menjadi lebih seragam sehingga meningkatkan komparabilitas informasi keuangan entitas antar negara. Hal ini dikarenakan penerapan standar 
yang seragam diyakini dapat meningkatkan komparabilitas atau keterbandingan laporan keuangan yang meningkatkan kebermanfaatan laporan keuangan itu sendiri. Meskipun IASB tidak menyatakan secara eksplisit penerapan IFRS menjadi standar pelaporan keuangan global, banyak negara yang telah mengadopsi IFRS menjadi acuan standar pelaporan keuangan melalui proses konvergensi. Hal ini menjadi salah satu tolak ukur pentingnya komparabilitas.

Kedudukan komparabilitas sebagai salah satu karakteristik kualitatif yang penting dalam laporan keuangan, membuat kita perlu memahami dengan baik faktor-faktor yang dapat menciptakan komparabilitas, di samping pemberlakuan standar yang seragam. Sehingga dapat diketahui bagaimana komparabilitas dapat terwujud dengan baik. Berbagai debat dan riset akuntansi belakangan ini banyak mengangkat isu komparabilitas dengan membahas faktor-faktor yang berperan meningkatkan komparabilitas. Tetapi debat maupun riset yang dilakukan hampir selalu menitikberatkan peran standar dalam menciptakan tatanan komparabilitas laporan keuangan seperti halnya adopsi IFRS (Barth et al., 2012; Lang et al., 2010).

Penelitian Ball et al. (2003) mengungkapkan bahwa merupakan suatu kesalahan dan cenderung menyesatkan apabila mengklasifikasikan negara berdasarkan kualitas standar pelaporan akuntansi yang digunakan, tanpa mempertimbangkan insentif dari pihak yang terlibat dalam proses pelaporan, seperti manajer dan auditor. Hal ini disebabkan karena pemberlakuan dan penerapan standar sangat erat kaitannya dengan insentif serta bersifat sensitif terhadap insentif dari pihak manajer dan auditor yang bertanggungjawab terhadap penyajian laporan keuangan. Penelitian ini menyajikan bukti empiris penggunaan-standar yang diyakini sebagai standar yang berkualitas dengan banyak negara yang telah mengadopsinya, seperti standar UK, US, dan IAS pada perusahaan-perusahaan di Hong Kong, Malaysia, Singapura, dan Thailand tidak menjamin kualitas yang baik pula pada laporan keuangan yang diterbitkan. Di mana ditemukan insentif pihak yang terlibat dalam proses pelaporan menyebabkan penyajian laporan keuangan dengan kualitas rendah meskipun di bawah acuan standar yang berkualitas.

Begitu pula penelitian Defond et al. (2011) menunjukkan bahwa kredibilitas pengimplementasian dan peningkatan keseragaman standar merupakan faktor penting dalam meningkatkan komparabilitas. Meskipun demikian, efek atau pengaruh dari pengadopsian standar akuntansi yang seragam secara kritis tergantung kepada institusi ekonomi dan insentif atau dorongan manajemen yang ikut memainkan peran dalam mewujudkan komparabilitas. Hal ini menunjukkan bahwa standar yang seragam bukanlah satu-satunya faktor yang dapat meningkatkan komparabilitas, mengingat terlibatnya berbagai pihak dalam proses pelaporan keuangan yang akan menentukan bagaimana suatu standar diinterpretasikan dan diterapkan.

Penerapan standar yang bersifat principle-based seperti halnya IFRS, memberikan ruang yang fleksibel bagi manajer maupun auditor dalam penerapan standar yang bersifat umum. Karaktristik standar semacam ini menuntut banyaknya penggunaan judgment profesional oleh auditor dalam proses auditing. Hal ini akan menimbulkan kekhawatiran bagi pengguna (users) apakah laporan keuangan dengan standar yang seragam masih tetap comparable (dapat dibandingkan). Kothari et al (2010) mengemukakan bahwa di bawah penerapan standar yang lebih principle-based, setiap auditor akan mengembangkan aturan kerja internal tersendiri yang akan mereka gunakan sebagai standarisasi atau panduan dalam interpretasi dan implementasi standar yang konsisten, dengan alasan efisiensi. Hal ini memungkinkan terdapatnya perbedaan interpretasi standar dari setiap auditor.

Penelitian Francis et al. (2014) merupakan penelitian pertama yang menguji hipotesis terkait bagaimana peran institusi ekonomi dalam hal ini auditor, dalam mewujudkan komparabilitas laporan keuangan. Menggunakan sampel perusahaan di US di bawah penerapan 
standar US GAAP, komparabilitas laporan keuangan dilihat dengan mengukur tingkat kemiripan accruals dan earnings structure. Menurut Francis et al. (2014) setiap auditor (dalam hal ini KAP) memiliki aturan dan standar kerja internal yang unik serta akan berbeda dalam interpretasi dan penerapan standar audit maupun standar akuntansi, hal ini yang kemudian disebut auditor style. Ditemukan bahwa perusahan yang diaudit oleh KAP Big 4 yang sama yang diasumsikan mendapatkan perlakuan style audit yang sama, memiliki tingkat komparabilitas akuntansi yang lebih besar dibandingkan dengan perusahaan yang diaudit oleh KAP Big 4 yang berbeda yang diasumsikan mendapatkan perlakuan style audit yang berbeda. Selain itu terdapat perbedaan tingkat comparable earnings antara perusahaan yang diaudit oleh KAP Big 4 dengan KAP nonBig 4. Hal ini meunjukkan setiap KAP memiliki style tersendiri dalam praktik interpretasi standar dan pendekatan audit di lapangan yang akan berpengaruh terhadap tingkat komparabilitas laporan keuangan klien.

Penelitian Francis et al (2014) sebelumnya telah melihat bagaimana auditor style di bawah naungan standar yang bersifat rule-based pun berimplikasi kepada tingkat komparabilitas laporan keuangan antar entitas di US, meskipun telah tersedia panduan (guidance) yang lebih jelas dan tegas di dalam standarnya. Dengan kata lain, auditor style memainkan peran yang cukup besar dalam terwujudnya komparabilitas laporan keungan di samping standar yang berlaku karena auditor merupakan pihak yang terlibat secara aktif dalam proses pelaporan keuangan.

Berdasarkan uraian di atas, penelitian ini bertujuan untuk menguji dan menyajikan bukti empiris bagaimana pengaruh auditor style yang mengacu pada penelitian Francis et al. (2014) terhadap tingkat komparabilitas laporan keuangan perusahaan di Indonesia. Proksi yang digunakan untuk melihat perbedaan auditor style adalah KAP Big 4 yang sama, KAP Big 4 yang berbeda, dan KAP non-Big 4. Di mana diasumsikan KAP yang sama cenderung akan memiliki style audit yang sama. Pengaruh auditor style terhadap komparabilitas laporan keuangan akan diukur dengan membandingkan terlebih dahulu komparabilitas laporan keuangan dengan menggunakan proksi kemiripan akrual dari pasangan perusahaan yang diaudit oleh KAP yang sama dan KAP yang berbeda yang kemudian akan dianalisis pengaruhnya melalui model regresi dengan mengontrol beberapa variabel yang mewakili karakteristik fundamental masing-masing perusahaan. Penelitian ini memilih periode penelitian dimulai pada saat penerapan PSAK konvergensi IFRS secara penuh untuk mecerminkan eksistensi pengaruh auditor style terhadap komparabilitas laporan keuangan di bawah penerapan standar yang principle-based.

Penelitian ini diharapkan dapat memberikan manfaat bagi berbagai pihak di samping mencapai tujuan penelitian. Di mana penelitian ini diharapkan dapat memberikan pemahaman yang lebih mendalam kepada peneliti mengenai makna komparabilitas atas laporan keuangan dan dapat memahami dengan lebih baik bagaimana auditor style sebagai faktor lain selain standar pelaporan yang dapat mempengaruhi tingkat komparabilitas laporan keuangan. Selain itu penelitian ini diharapkan ikut memberikan kontribusi untuk digunakan dalam melakukan analisa isi atau konten informasi yang ada dalam laporan keuangan dengan menjadikan auditor style sebagai salah satu hal yang dipertimbangkan dalam menilai komparabilitas atas laporan keuangan di samping penggunaan standar pelaporan yang seragam untuk menghasilkan penilaian maupun keputusan yang lebih baik. Serta dapat menjadi suatu ide dalam pengembangan penelitian berikutnya terkait komparabilitas laporan keuangan dengan berbagai pengembangan dan penyempurnaan. 


\section{REVIU LITERATUR DAN HIPOTESIS \\ Kajian Teori}

\section{Komparabilitas Laporan Keuangan}

Definisi komparabilitas telah dikemukakan oleh berbagai badan otoritas akuntansi, penulis buku teks akuntansi, maupun oleh para peneliti di bidang akuntansi. Di mana Financial Accounting Standard Board (FASB), badan yang bertanggungjawab atas perumusan standar akuntansi di Amerika Serikat dan International Accounting Stadards Board (IASB) badan standar akuntansi internasional, menyatakan komparabilitas sebagai kualitas informasi yang memungkinkan pengguna laporan keuangan mengidentifikasi perbedaan dan persamaan kinerja keuangan dua perusahaan. Komparabilitas menjadi karakteristik dasar yang dapat meningkatkan kebermanfaatan laporan keuangan (FASB, 2008; IASB, 2008 dalam Butar, 2017). Ikatan Akuntan Indonesia (IAI) juga menyatakan hal yang serupa bahwa komparabilitas sangat diperlukan dalam meningkatkan kemampuan pengguna laporan keuangan untuk mengidentifikasi kecenderungan posisi keuangan dan menilai perubahan posisi keuangan.

Komparabilitas atau keterbandingan (comparability) dalam buku-buku teks akuntansi didefinisikan sebagai unsur tambahan yang menjadikan informasi bermanfaat yang berarti kemampuan informasi untuk membantu para pemakai mengidentifikasi persamaan dan perbedaan antara dua perangkat fenomena ekonomik (Suwarjdono, 2005:175). Sedangkan menurut Lam (2014:27) komparabilitas merupakan salah satu karakteristik kualitatif laporan keuangan yang berarti tingkat keterbandingan laporan keuangan.

Komparabilitas memungkinkan pengguna untuk mengidentifikasi dan memahami kesamaan dan perbedaan antar-item. Di mana komparabilitas membantu pengguna untuk melakukan analisis seri waktu (atau tren/time series), yang membandingkan laporan keuangan suatu entitas selama periode waktu untuk mengidentifikasi tren dalam posisi keuangan dan kinerja suatu entitas; serta membantu pengguna dalam melakukan analisis lintas bagian (crosssectional), yang membandingkan laporan keuangan antar entitas yang berbeda untuk mengevaluasi posisi keuangan, kinerja, dan arus kas secara relatif (Lam, 2014:27).

Francis et al. (2014) mengartikan lebih detail komparabilitas akuntansi dengan bagaimana kedekatan atau kemiripan antara dua perusahaan dalam melaporkan earnings berdasarkan konsistensi aturan yang diterapkan antar perusahaan. Di mana perusahaan yang mempunyai komparabilitas akuntansi atas informasi keuangannya akan cenderung memiliki kemiripan accruals dan earnings structure. Hal ini akan memudahkan pengguna dalam melakukan perbandingan informasi keuangan antar perusahaan. Di samping itu, Wang (2014) berpendapat sama, bahwa komparabilitas merupakan korelasi antara proses pengukuran earnings dua perusahaan.

Komparabilitas atau keterbandingan sangat erat kaitannya dengan konsistensi (Suwardjono, 2005:177). Pendapat yang sama juga dinyatakan oleh Lam (2014:28), bahwa untuk memungkinkan dan meningkatkan komparabilitas, pengukuran, dan penyajian efek keuangan atas transaksi dan peristiwa lainnya harus dilakukan dengan cara yang konsisten pada suatu entitas dan dari waktu ke waktu untuk entitas tersebut dan dengan cara yang konsisten untuk entitas yang berbeda. Kepatuhan terhadap standar (dalam hal ini IFRS) termasuk pengungkapan kebijakan akuntansi yang digunakan oleh entitas, membantu tercapainya komparabilitas.

DeFond et al. (2011) memberikan pernyataan yang lebih tegas terkait pnerapan standar yang seragam dalam meningkatkan komparabilitas. Di mana menurut mereka penerapan standar yang seragam seperti IFRS hanya akan meningkatkan komparabilitas apabila diterapkan atau 
diaplikasikan dengan jujur dan dengan tingkat kredibilitas yang tinggi. Tentunya hal ini melibatkan pihak-pihak yang bertanggung jawab dalam proses pelaporan keuangan seperti manajer dan auditor, karena pengaplikasian standar yang bersifat principle-based seperti IFRS memberikan ruang untuk bersikap fleksibel dalam menetapkan suatu kebijakan akuntansi. Begitu pula Butar (2017) menyatakan bahwa secara prinsip laporan dua perusahaan hanya bisa dibandingkan jika kebijakan dan standar yang mendasari penyusunan laporan keuangan tersebut telah diterapkan secara konsisten dari tahun ke tahun dan dari satu negara dengan negara lainnya.

Studi-studi terkait komparabilitas menyimpulkan bahwa meskipun standar merupakan faktor yang sangat berpengaruh dalam terwujudnya komparabilitas, Ball et al. (2003) dan Leuz et al. (2003) menyatakan bahwa standar saja tidak dapat secara penuh menentukan produk atau hasil proses pelaporan keuangan, di mana agen ekonomi dan insentif atau dorongan institusi ekonomi juga ikut memainkan peran penting dalam mewujudkan komparabilitas.

Penelitian Francis et al. (2014) merupakan penelitian pertama yang mengaitkan isu komparabilitas dengan auditor. Mereka menyatakan bahwa setiap Kantor Akuntan Publik-KAP akan memiliki perbedaan dalam penafsiran atau interpretasi dan implemetansi standar akuntansi. Di mana setiap KAP terutama Big 4, memiliki aturan kerja internal berbeda yang akan mengarahkan auditor dalam pengaplikasian standar akuntansi dalam proses audit, seperti terdapatnya perbedaan pendekatan audit oleh setiap KAP. Hal ini dapat saja menurunkan tingkat komparabilitas laporan keuangan antar perusahaan klien. Dengan demikian, di samping keseragaman standar, auditor juga merupakan faktor yang mempengaruhi terwujudnya tatanan komparabilitas laporan keuangan.

Berdasarkan perkembangan riset-riset terkait komparabilitas, dapat disimpulkan bahwa selain penerapan standar yang seragam, faktor lain seperti agen ekonomi dan keberadaan institusi merupakan hal yang perlu dipertimbangkan untuk menjamin bahwa penerapan standar telah sesuai dengan kondisi ekonomi yang melatarbelakanginya serta menjamin konsistensi penerapan standar tersebut, sehingga komparabilitas yang dapat meningkatkan kebermanfaatn laporan keungan bagi para pengguna laporan keuangan dapat terwujud.

\section{Karakteristik Auditor dan Atribut Laba}

Auditor merupakan pihak yang bertanggungjawab dalam upaya menghasilkan laporan keuangan yang dapat diandalkan untuk kepentingan pengguna dalam pengambilan keputusan melalui proses auditing. Butar (2017) menyatakan bahwa pengauditan memiliki arti penting karena kemampuannya memberikan keyakinan kepada pengguna, di mana laporan keuangan yang telah diaudit lebih dapat diandalkan untuk pengambilan keputusan ekonomik dibandingkan laporan keuangan yang belum diaudit. Namun, manfaat pengauditan hanya akan terwujud jika proses pengauditan dilakukan secara profesional dan independen. Hal ini akan terlihat dari output yang dihasilkan dari proses audit. Di mana Butar (2017) menyimpulkan bahwa terdapat keterkaitan yang erat antara output audit dengan auditor yang melakukan tugas pengauditan.

DeFond et al. (2014) dalam Butar (2017) mengemukakan bahwa salah satu faktor yang dapat meningkatkan kualitas audit adalah karakteristik auditor. Di mana karakteristik auditor yang dimaksud adalah keanggotan auditor dalam salah satu kantor akuntan yang masuk kategori Big Four dan spesialisasi industri auditor. Mereka menggunakan keanggotaan dalam kantor akuntan publik Big Four sebagai proksi kualitas audit dengan argumen bahwa kantor akuntan yang besar memiliki dorongan yang besar pula untuk menjaga reputasinya sehingga cenderung akan mempekerjakan auditor dengan kompetensi tinggi. Sehingga kualitas audit yang dimiliki auditor dari kantor akuntan Big Four diekspektasi lebih tinggi daripada auditor dari kantor 
akuntan non-Big Four. Selain itu auditor spesialis juga memiliki kompetensi tinggi yang berhubungan positif dengan kualitas auditnya.

Menurut Kothari et al. (2010), perbedaan dalam praktik pengauditan lebih mungkin terjadi ketika standar yang dikembangkan lebih berorientasi pada prinsip (principle-based) dari pada berorientasi pada aturan (rule-based). Mereka menjelaskan bahwa standar akuntansi yang bebasis prinsip lebih mendorong auditor untuk mengembangkan aturan-aturan kerja agar implementasi serta interpretasi standar dapat dilakukan secara efisien. Butar (2017) mengemukakan bahwa kebijakan audit spesifik yang dimiliki kantor akuntan merupakan produk dari pengalaman panjang yang ditambah dengan pengetahuan unik yang dimiliki auditor mengenai lingkungan bisnis klien. Hal ini akan memungkinkan kantor akuntan mengembangkan cara unik dan spesifik dalam menilai penerapan standar akuntansi oleh klien.

\section{Auditor Style}

Auditor style didefinisikan oleh Francis et al. (2014) dengan metodologi audit dan prosedur pengujian unik yang dimiliki kantor akuntan publik, terutama kantor akuntan Big Four. Di mana mereka menyatakan bahwa kantor akuntan Big Four memiliki pendekatan audit yang unik dan berbeda dalam pengimplementasian standar pengauditan yang telah ditetapkan badan otoritas yang berwenang. Pendekatan audit yang unik ini diwujudkan dalam bentuk aturan-aturan atau prosedur kerja yang spesifik dalam menginterpretasi penerapan prinsip-prinsip akuntansi yang dijalankan oleh perusahaan klien.

Metode dan prosedur audit harus mengikuti standar audit yang berterima umum di suatu negara. Meskipun demikian, Butar (2017) dan Francis et al. (2014) menyatakan bahwa standar audit yang ditetapkan bersifat umum, sehingga kantor akuntan harus mengembangkan aturanaturan kerja (working rules) masing-masing untuk menilai apakah standar akuntansi telah diterapkan secara tepat dan konsisten pada semua klien yang mereka audit. Francis et al. (2014) berpendapat bahwa setiap KAP Big 4 memiliki standar dan pedoman kerja internal yang berbeda, yang akan berpengaruh kepada praktik audit oleh auditor di lapangan. Hal ini dibuktikan dengan memberikan bukti empiris bahwa auditor style yang diproksikan dengan KAP Big 4 dan KAP non-Big 4 memiliki perbedaan dalam interpretasi dan pengaplikasian standar akuntansi yang kemudian membedakan pendekatan dan prosedur audit yang dilakukan.

Kothari et al. (2010), menyatakan perbedaan dalam praktik pengauditan lebih mungkin terjadi ketika standar yang dikembangkan lebih berorientasi pada prinsip (principle-based) dari pada berorientasi pada aturan (rule-based). Mereka menjelaskan bahwa standar akuntansi yang bebasis prinsip lebih mendorong auditor untuk mengembangkan aturan-aturan kerja agar implementasi serta interpretasi standar dapat dilakukan secara efisien. Dimana Francis et al. (2014) dan Butar (2017) menyajikan perbedaan pedoman penerapan standar akuntansi yang digunakan secara internal oleh para auditor kantor akuntan Big Four di lapangan, meskipun tersedia standar global yaitu IFRS, sebagai dampak dari sifat standar yang umum yang menyebabkan setiap KAP Big 4 memiliki interpretasi standarnya masing-masing. Berikut produk yang dikembangkan masing-masing KAP Big 4:

a) Ernst \& Young (E\&Y) menyebutkan produk mereka Global Accounting and Auditing Information Tool sebagai sebuah sumber online yang dapat digunakan secara global dalam menginterpretasi standar akuntansi dan pengauditan.

b) Deloitte menerbitkan Deloitte Technical Library yang memberikan petunjuk dalam menginterpretasi standar akuntansi. 
c) KPMG menerbitkan panduan interpretasi standar yang dimuat dalam Accounting Research Online.

d) PricewaterhouseCoopers $(\mathrm{PwC})$ menyajikan produk panduan interpretasi standar mereka dalam Accounting Guides.

Setiap KAP Big 4 secara eksplisit menyatakan bahwa produk mereka menyajikan panduan (guidance) untuk menginterpretasikan dan mengaplikasikan standar akuntansi maupun pengauditan. Panduan ini tersedia untuk penggunaan internal oleh staf serta tersedia panduan interpretasi standar akuntansi bagi klien secara global dengan sistem subscription dengan subscription price yang berbeda-beda. Di mana klien biasanya akan cenderung menggunakan dan mengikuti petunjuk dan arahan dari auditornya dalam menyajikan laporan keuangan.

Pedoman dan aturan kerja internal yang diciptakan masing-masing KAP tersebut akan berdampak pada terdapatnya perbedaan yang sistematis terkait penetapan pendekatanpendekatan audit, interpretasi, dan penerapan standar akuntansi di masing-masing KAP (Francis et al., 2014). Hal ini yang kemudian menjadikan terdapatnya perbedaan praktik audit oleh setiap auditor, sebagaimana yang dijelaskan sebelumnya, hal ini disebut auditor style. Sehingga implikasinya adalah laporan keuangan akan lebih dapat diperbandingkan apabila diaudit dengan style audit yang sama.

\section{Pengembangan Hipotesis}

Penelitian ini menggunakan dua hipotesis prediksi yang nantinya akan menggambarkan dan menjelaskan bagaimana auditor style dapat mempengaruhi komparabilitas laporan keuangan antar perusahaan. Di mana komparabilitas dilihat dari tingkat kemiripan accruals dengan merujuk kepada penelitian utama yaitu penelitian Francis et al (2014) dan Butar (2017).

Penelitian DeFond et al. (2011) menunjukkan bahwa keseragaman penerapan standar akuntansi saja tidak dapat secara penuh mewujudkan komparabilitas, meskipun komparabilitas itu sendiri sangat berkaitan erat dengan penerapan kesatuan standar yang seragam. Di mana hal serupa juga telah dinyatakan oleh Ball et al. (2003) bahwa penerapan standar yang seragam saja tidak secara penuh dapat menentukan produk atau hasil dari proses pelaporan keuangan, di mana agen ekonomi dan dorongan institusi ekonomi juga memainkan peran penting dalam mewujudkan komparabilitas. Dalam hal ini auditor ikut andil dalam mewujudkan komparabilitas laporan keuangan.

Barth et al. (2012) menyatakan bahwa pelaporan keuangan merupakan hasil dari interaksi yang kompleks dalam sistem pelaporan keuangan yang termasuk di dalamnya standar akuntansi dan interpretasinya, penerapan standar, dan litigasi, yang di mana semua hal ini dapat mempengaruhi komparabilitas. Auditor merupakan pihak yang terlibat secara aktif dalam rangkaian sistem pelaporan keuangan tersebut yang akan melakukan verifikasi atas angka laporan keuangan sebelum sampai kepada para pengguna.

Francis et al. (2014) berpendapat bahwa setiap KAP memiliki aturan kerja internal dan pendekatan-pendekatan yang berbeda dalam interpretasi dan penerapan standar. Selain itu penggunaan standar yang bersifat principle-based menjadikan auditor bekerja penuh dengan pertimbangan (judgment), yang akan berdampak kepada komparabilitas laporan keuangan klien. Selain itu, Francis et al. (2014) juga membuktikan satuan aturan kerja dari masing-masing KAP Big 4 merupakan mekanisme penting terkait bagaimana suatu standar akan dapat dijalankan dan diterapkan antara auditor dengan klien. Di mana ditemukan bahwa terdapat kecenderungan klien yang diaudit oleh KAP Big 4 yang sama untuk menginterpretasikan dan mengimplementasikan standar dengan cara yang sama pula. Sehingga apabila auditor style memberikan pengaruh 
kepada penyajian laporan keuangan klien, perlu dilihat bagaimana tingkat konsistensi laporan keuangan antara dua perusahaan dengan jenis usaha dan periode pelaporan yang sama, yang diaudit oleh KAP Big 4 yang sama dibandingkan dengan dua perusahaan yang diaudit oleh KAP Big 4 yang berbeda. Dengan demikian, hipotesis pertama dapat dirumuskan sebagai berikut:

H1: Sepasang perusahaan yang diaudit oleh KAP Big 4 yang sama akan memiliki earnings yang lebih comparable dibandingkan dengan sepasang perusahaan yang diaudit oleh dua KAP Big 4 yang berbeda.

Francis et al. (2014) berpendapat bahwa penerapan standar dan aturan kerja internal harus diimplementasikan secara tepat. Berbagai penelitian terkait kualitas audit oleh para peneliti telah menunjukkan terdapatnya perbedaan kualitas audit antara KAP Big 4 dengan KAP non-Big 4. Perbedaan kapasitas dan aturan kerja internal dalam interpretasi dan penerapan standar oleh KAP Big 4 dan KAP non-Big 4 akan mempengaruhi tingkat komparabilitas informasi keuangan masing-masing klien (Francis et al., 2014). Selain itu, KAP Big 4 memiliki satuan staf dengan bidang keahlian yang lebih banyak, yang memiliki insentif yang lebih besar dalam mengontrol stafnya dibandingkan dengan KAP non-Big 4. Sehingga diasumsikan perusahaan yang diaudit oleh KAP Big 4 akan mengaplikasikan standar secara lebih konsisten dan atas dasar yang tepat yang akan meningkatkan komparabilitas informasi keuangan klien. Oleh karena itu, hipotesis kedua dirumuskan sebagai berikut:

H2: Sepasang perusahaan yang diaudit oleh KAP Big 4 yang sama akan memiliki earnings yang lebih comparable dibandingkan dengan sepasang perusahaan yang diaudit oleh KAP non-Big 4 yang sama.

\section{METODE PENELITIAN}

Penelitian ini merupakan penelitian kausatif. Di mana penelitian ini merupakan penelitian yang akan menguji serta menyajikan bukti empiris bagaimana pengaruh auditor style terhadap tingkat komparabilitas laporan keuangan perusahaan. Menggunakan populasi seluruh perusahaan manufaktur yang terdaftar di Bursa Efek Indonesia (BEI) pada tahun 2012 hingga 2016. Penentuan sampel dalam penelitian ini menggunakan metode purposive sampling, dengan beberapa criteria yang disesuaikan dengan tujuan penelitian sebagai berikut:

a. Perusahaan manufaktur yang terdaftar di Bursa Efek Indonesia periode 2012-2016 serta konsisten menerbitkan laporan keuangan lengkap yang telah diaudit selama periode 2012-2016.

b. Perusahaan manufaktur yang menggunakan periode pelaporan 31 Desember.

c. Perusahaan manufaktur yang menggunakan mata uang Rupiah sebagai mata uang fungsional/pelaporan.

d. Perusahaan manufaktur yang tidak melakukan pergantian auditor selama tahun pengamatan.

e. Perusahaan manufaktur yang melaporkan angka earnings/laba bersih dan arus kas dari aktivitas operasi/cash flows from operations positif selama tahun pengamatan.

Data dalam penelitian ini merupakan data yang diperoleh dari situs resmi Bursa Efek Indonesia (www.idx.co.id) yaitu data laporan keuangan perusahaan manufaktur yang terdaftar di Bursa Efek Indonesia pada tahun 2012 hingga 2016 terkait data-data dari laporan keuangan yang dibutuhkan dalam model penelitian. 
Variabel penelitian auditor style dan komparabilitas laporan keuangan akan diolah menggunakan aplikasi pengolah data SPSS 20 dengan uji Regresi Berganda.

Untuk memudahkan penulisan serta demi menghindari perbedaan penafsiran dalam penelitian ini, maka berikut penjelasan definisi operasional variabel dalam penelitian ini: 1) Komparabilitas Laporan Keuangan didefinisikan sebagai kedekatan atau kemiripan dari dua perusahaan yang melaporkan laba berdasarkan konsistensi penerapan standar atau aturan antar perusahaan tersebut. Di mana penelitian ini berasumsi sepasang perusahaan dalam jenis perusahaan yang sama dan tahun pelaporan yang sama akan memiliki kemiripan akrual; 2) Auditor Style didefinisikan dengan metodologi audit dan prosedur pengujian unik yang dimiliki oleh setiap kantor akuntan publik. Penelitian ini berasumsi setiap KAP Big-4 memiliki perbedaan yang sistematis dalam pendekatan auditnya serta dalam interpretasi dan penerapan standar. Di mana setiap KAP Big-4 mengembangkan aturan atau kebijakan kerja internal yang unik di masing-masing KAP yang akan dijadikan sebagai pedoman dan standarisasi bagi para auditornya dalam aplikasi audit dan standar akuntansi di lapangan.

\section{HASIL DAN PEMBAHASAN Hasil Penelitian}

Setelah melalui beberapa uji asumsi dengan menggunakan aplikasi pengolah data SPSS 20, dilakukan analisis regresi terhadap data penelitian untuk menguji pengaruh variabel Auditor Style terhadap Komparabilitas Laporan Keuangan. Hasil analisis regresi dilampirkan pada bagian akhir artikel ini.

Berdasarkan tabel hasil regresi (tabel dilampirkan) untuk hipotesis 1, diketahui bahwa nilai sig dari variabel independen (SameBig4) sebesar 0,009 < alpha 0,05 yang menunjukkan bahwa auditor style berpengaruh signifikan terhadap komparabilitas laporan keuangan. Sedangkan untuk hipotesis 2, nilai sig dari variabel independen (SameBig4) adalah 0,623 > alpha 0,05 yang berarti bahwa auditor style tidak berpengaruh signifikan terhadap komparabilitas laporan keuangan.

Berdasarkan hasil estimasi pada tabel hasil uji regresi model (tabel lampiran 5 dan 6) hipotesis 1 , dapat diketahui bahwa nilai adjusted $R^{2}$ yang diperoleh adalah 0,991 . Hal ini dapat diartikan bahwa perubahan pada variabel independen (auditor style) pada hipotesis 1 dapat menjelaskan perubahan variabel dependen (komparabilitas laporan keuangan) sebesar 99\% dan $1 \%$ ditentukan oleh variabel lain yang tidak dianalisis dalam penelitian ini.

Sedangkan untuk hasil uji regresi model hipotesis 2 , diperoleh nilai adjusted $R^{2}$ adalah 0,026 yang berarti bahwa perubahan pada variabel independen (auditor style) pada hipotesis 2 hanya dapat menjelaskan perubahan variabel dependen (komparabilitas laporan keuangan) sebebsar 2,6\% sedangkan 97,4\% lagi ditentukan oleh variabel lain yang tidak dianalisis dalam penelitian ini.

\section{Pembahasan Hasil Penelitian}

Variabel komparabilitas laporan keuangan diukur dengan menggunakan salah satu atribut/komponen laba, yaitu akrual. Di mana akrual diyakini merupakan salah satu komponen laba yang sangat erat kaitannya dengan tindakan discretionary manajer serta komponen yang dapat secara langsung dipengaruhi oleh auditor. Dechow \& Dichev (2002) dalam Butar (2017) memprediksi bahwa kualitas laba dan kualitas akrual akan menurun seiring dengan meningkatnya ketidaktepatan estimasi. 
Variabel auditor style diproksikan dengan KAP Big 4 dan KAP Non-Big 4. Hal ini berdasarkan penelitian terdahulu, seperti Francis et al (2014) dan Butar (2017) yang memaparkan berbagai literatur dan teori mengenai terdapatnya perbedaan gaya audit dari setiap KAP, baik itu tercermin dalam pendekatan audit yang dipilih, pengimplementasian standar yang digunakan, maupun inovasi-inovasi jasa audit yang disediakan. Sehingga auditor style diduga menjadi salah satu faktor yang menentukan dalam mencapai komparabilitas laporan keuangan.

Berikut disajikan pembahasan hasil uji hipotesis untuk masing-masing hipotesis penelitian.

a. Hipotesis 1: Sepasang perusahaan yang diaudit oleh KAP Big 4 yang sama akan memiliki earnings yang lebih comparable dibandingkan dengan sepasang perusahaan yang diaudit oleh dua KAP Big 4 yang berbeda.

Berdasarkan hasil penelitian selama lima tahun pengamatan dari 2012-2016, melalui pengolahan data SPSS 20 dapat dilihat pada perusahaan manufaktur untuk hipotesis 1 diperoleh cukup bukti bahwa auditor style berpengaruh signifikan terhadap komparabilitas laporan keuangan yang menunjukkan terdapatnya pengaruh signifikan antara KAP Big 4 terhadap komparabilitas laporan keuangan. Di mana sepasang perusahaan yang diaudit oleh KAP Big 4 yang sama memilki tingkat komparabilitas yang lebih tinggi di samping diaudit oleh KAP Big 4 yang berbeda.

Hasil ini tidak konsisten dengan penelitian sebelumnya yang dilakukan oleh Francis et al (2014) dan Butar (2017). Di mana peneliti sebelumnya menemukan bahwa tidak terdapat pengaruh yang signifikan antara auditor style dengan komparabilitas laporan keuangan. Perbedaan hasil penelitian ini mugkin disebabkan oleh rentang waktu penelitian dan pemilihan sampel penelitian dengan penerapan standar pelaporan yang berbeda. Francis et al (2014) menggunakan sampel perusahaan manufaktur yang menggunakan standar pelaporan US GAAP yang merupakan standar yang bersifat rule-based. Sedangkan peneliti memilih sampel yang menggunakan standar pelaporan PSAK konvergensi IFRS yang merupakan standar yang bersifat principle-based. Hal ini mungkin memberikan pengaruh terhadap perbedaan hasil penelitian yang diperoleh.

Selain itu perbedaan hasil penelitian ini dengan penelitian Butar (2017) berkemungkinan disebabkan oleh penetapan periode penelitian dengan rentang waktu yang berbeda. Butar (2017) memilih periode penelitian dari tahun 2010 hingga 2015. Di mana pada periode tersebut terdapat masa transisi standar di Indonesia, yaitu konvergensi standar dari PSAK menjadi PSAK konvergensi IFRS. Sedangkan peneliti memilih periode penelitian dimulai sejak tahun 2012 yang merupakan tahun konvergensi penuh PSAK IFRS di Indoensia.

b. Hipotesis 2: Sepasang perusahaan yang diaudit oleh KAP Big 4 yang sama akan memiliki earnings yang lebih comparable dibandingkan dengan sepasang perusahaan yang diaudit oleh KAP non-Big 4 yang sama.

Hasil penelitian untuk hipotesis 2 sejalan dengan penelitian sebelumnya yang dilakukan Francis et al (2014) dan Butar (2017), di mana tidak ditemukan bukti yang kuat bahwa terdapat perbedaan pengaruh auditor style antara KAP Big 4 dengan KAP Non-Big 4 terhadap tingkat komparabilitas laporan keuangan. Hasil ini tidak konsisten dengan hipotesis 1, yang berkemungkinan disebabkan karena perbedaan jenis industri dari perusahaan sampel yang diolah. Di mana perusahaan dari jenis industri yang berbeda tentu memiliki perbedaan makna 
penafsiran angka laporan keuangan yang tidak dapat dimaknai sebagaimana perusahaan dari industri sejenis. Selain itu, perbedaan ini mungkin juga dapat disebabkan oleh jumlah sampel pasangan perusahaan yang tidak seimbang antara pasangan perusahaan yang diaudit oleh KAP Big 4 yang sama dengan pasangan perusahaan yang diaudit oleh KAP Non-Big 4 yang sama. Ketidakseimbangan jumlah pasangan perusahaan dikarenakan ditemukannya frekuensi pergantian auditor yang cukup tinggi yang dilakukan oleh perusahaan yang diaudit oleh KAP Non-Big 4. Sehingga tidak terdapat cukup banyak sampel perusahaan yang menggunakan auditor dari KAP Non-Big 4 yang sama berturut-turut selama periode pengamatan. Hal ini berkemungkinan menyebabkan hasil pengujian yang tidak konsisten dengan hasil pengujian hipotesis 1.

\section{SIMPULAN, KETERBATASAN, DAN SARAN \\ Kesimpulan}

Analisis yang telah dilakukan pada perusahaan manufaktur dengan periode penelitian dari tahun 2012 hingga 2016 di atas, mengarahkan kepada penarikan kesimpulan sebagai berikut:

1. Diperoleh cukup bukti dari hasil analisis bahwa variabel Auditor Style mempengaruhi tingkat komparabilitas atau keterbandingan laporan keuangan. Temuan ini mengindikasikan bahwa penggunaan KAP Big 4 yang sama antara dua perusahaan cenderung meningkatkan komparabilitas kedua perusahaan tersebut. Selain itu, ditemukan bukti yang cukup kuat bahwa penggunaan KAP Big 4 yang berbeda oleh dua perusahaan, dapat menurunkan tingkat komparabilitas laporan keuangan antar perusahaan tersebut.

2. Tidak ditemukan cukup bukti bahwa terdapat perbedaan antara KAP Big 4 maupun KAP Non-Big 4 dalam memberi pengaruh terhadap tingkat komparabilitas laporan keuangan perusahaan.

\section{Keterbatasan}

Berikut beberapa keterbatasan dalam penelitian ini:

1. Sampel yang digunakan adalah perusahaan manufaktur dengan penggunaan teknik purposive sampling dengan beberapa kriteria, sehingga hasil penelitian tidak dapat digunakan untuk pengambilan kesimpulan secara umum atau tidak dapat digeneralisasi.

2. Pengukuran komparabilitas hanya menggunakan salah satu atribut laba, yaitu akrual.

\section{Saran}

Berdasarkan kesimpulan dan keterbatasan penelitian di atas, beberapa saran yang dianjurkan untuk peneliti berikutnya adalah:

1. Menggunakan sampel penelitian dari jenis perusahaan yang lebih beragam agar pengaruh dari Auditor Style terhadap komparabilitas laporan keuangan dapat lebih tergambar secara jelas.

2. Dapat menggunakan kovarians angka laba dari masing-masing perusahaan dalam mengukur tingkat komparabilitas laporan keuangan di samping meggunakan akrual, serta dapat pula menambahkan variabel lain sebagai variabel moderating untuk menguji pengaruh auditor style terhadap laporan keuangan. 


\section{DAFTAR PUSTAKA}

Ball, R., Robin, A. and Wu, J. S. (2003). Incentives versus Standards: Properties of Accounting Income in Four East Asian Countries. Journal of Accounting and Economics, 36 (1-3): 235-270.

Barth, M. E., Landsman, W. R., Lang, M. and Williams, C. (2012). Are IFRS-based and US GAAP-based Accounting Amounts Comparable? Journal of Accounting and Economics, 54 (1): 68-93.

Becker, C. L., DeFond, M. L., Jiambalvo, J. and Subramanyam, K. R. (1998). The Effect of Audit Quality on Earnings Management. Contemporary Accounting Research, 15 (1): 124.

Boone, J., Khurana, I. K., and Raman, K. (2010). Do the Big 4 and the Second-Tier Firms Provides Audits of Similar Quality? Journal of Accounting and Public Policy, 29 (4): 330-52.

Butar, S. B. (2017). Implikasi Gaya Audit terhadap Komparabilitas Laporan Keuangan. Jurnal Dinamika Akuntansi dan Bisnis, 4(2): 189-210.

Cassell, C., Giroux, G., Meyers, L. and Omer, T. (2013). The Emergence of Second-Tier Auditors in the US: Evidence from Investor Perceptions on Financial Reporting Credibility. Journal of Business Finance and Accounting, 40 (3-4): 350-372.

DeFond, M., Hu, X., Hung, M., and Li, S. (2011). The Impact of Mandatory IFRS Adoption on Foreign Mutual Fund Ownership: The Role of Comparability. Journal of Accounting and Economics, 51 (3): 240-258.

DeFranco, G., Kothari, S. P. and Verdi, R. (2011). The Benefits of Financial Statements Comparability. Journal of Accounting Research, 49 (4): 895-931.

Francis, J. R., Pinnuck, M.L. \& Watanabe, O. (2014). Auditor Style and Financial Statement Comparability. The Accounting Reveiew, 89 (2): 605-663.

Francis, J., Maydew, L. E. and Sparks, H. C. (1999). The Role of Big 6 Auditors in the Credible Reporting of Accruals. Auditing: A Journal of Practice and Theory, 18 (2): 17-34.

Gordon, I. and Gallery, N. (2012). Assessing Financial Reporting Comparability Across Institutional Settings: The Case of Pension Accounting. The British Accounting Review, 44(2012):11-20.

Gujarati, D. N. (2004). Basic Econometrics. New York: McGraw-Hill Companies.

Ikatan Akuntan Indonesia. (2013). Pernyataan Standar Keuangan 01: Penyajian Laporan Keuangan (Revisi 2013). Jakarta: IAI.

Kothari, S. P., Ramana, K. and Skinner, D. (2010). Implications for GAAP from an Analysis of Positive Research in Accounting. Journal of Accounting and Economics, 50 (2-3): 246286.

Lam, N. and Lau, P. (2014). Akuntansi Keuangan: An IFRS Perspective. Jakarta: Salemba Empat.

Lang, M., Maffet, and Owens, E. (2010). Earning Comovement and Accounting Comparability: The Effects of Mandatory IFRS Adoption. Working Paper, The University of North Carolina, The University of Chicago, and University Rochester.

Reichelt, K. and Wang, D. (2010). National and Office-Specific Measures of Auditor Industry Expertise and Effects on Audit Quality. Journal of Accounting Research, 48 (3): 647-686.

Suwardjono. (2005). Teori Akuntansi: Perekayasaan Pelaporan Keuangan. Yogyakarta: BPFE.

Wang, C. (2014). Accounting Standards Harmonization and Financial Statement Comparability: Evidence from Transnational Information Transfer. Journal of Accounting Research. 


\section{LAMPIRAN}

Lampiran 1: Data Hasil Analisis Deskriptif Sampel Hipotesis 1 dan 2

Descriptive Statistics

\begin{tabular}{|l|r|r|r|r|r|r|r|r|r|r|}
\hline & \multicolumn{2}{|c|}{$\mathrm{N}$} & \multicolumn{2}{c|}{ Minimum } & \multicolumn{2}{c|}{ Maximum } & \multicolumn{2}{c|}{ Mean } & \multicolumn{2}{c|}{ Std. Deviation } \\
\cline { 2 - 10 } & $\mathrm{H} 1$ & $\mathrm{H} 2$ & $\mathrm{H} 1$ & $\mathrm{H} 2$ & $\mathrm{H} 1$ & $\mathrm{H} 2$ & $\mathrm{H} 1$ & $\mathrm{H} 2$ & $\mathrm{H} 1$ & $\mathrm{H} 2$ \\
\hline DiffTA & 485 & 235 &,- 1931 &, 0001 &, 2807 &, 1955 &,- 009478 &, 049796 &, 0734641 &, 0375221 \\
SameBig4 & 485 & 235 & 0 & 0 & 1 & 1 &, 47 &, 94 &, 500 &, 245 \\
ROA & 485 & 235 &,- 2970 &, 0003 &, 2856 &, 2241 &, 018992 &, 064860 &, 0942305 &, 0467855 \\
CFO & 485 & 235 &,- 3157 &, 0002 &, 3202 &, 2186 &, 026998 &, 063487 &, 0963974 &, 0463007 \\
Valid N (listwise) & 485 & 235 & & & & & & & & \\
\hline
\end{tabular}

Lampiran 2: Data Hasil Uji Normalitas Hipotesis 1 dan 2

One-Sample Kolmogorov-Smirnov Test

\begin{tabular}{|ll|r|r|}
\hline & & \multicolumn{2}{|c|}{ Unstandardized Residual } \\
\cline { 3 - 4 } & & $\mathrm{H} 1$ & \multicolumn{1}{c|}{$\mathrm{H} 2$} \\
\hline $\mathrm{N}$ & & 485 & 235 \\
Normal Parameters ${ }^{\mathrm{a}, \mathrm{b}}$ & Mean &, 0000000 &, 0000000 \\
& Std. Deviation &, 00693637 &, 03703874 \\
& Absolute &, 076 &, 079 \\
Most Extreme Differences & Positive &, 069 &, 079 \\
& Negative &,- 076 &,- 071 \\
Kolmogorov-Smirnov Z & & 1,678 & 1,210 \\
Asymp. Sig. (2-tailed) & &, 007 &, 107 \\
\hline
\end{tabular}

a. Test distribution is Normal.

b. Calculated from data.

Lampiran 3: Hasil Uji Heteroskedastisitas Hipotesis 1

Coefficients $^{a}$

\begin{tabular}{|c|c|c|c|c|c|c|}
\hline \multirow[t]{2}{*}{ Mode } & & \multicolumn{2}{|c|}{ Unstandardized Coefficients } & Standardized & \multirow[t]{2}{*}{$\mathrm{t}$} & \multirow[t]{2}{*}{ Sig. } \\
\hline & & $B$ & Std. Error & Beta & & \\
\hline \multirow{4}{*}{1} & (Constant) & , 005 & ,000 & & 15,513 & , 000 \\
\hline & SameBig4 & , 000 & , 000 &,- 032 &,- 700 & 485 \\
\hline & ROA & , 002 & , 003 & -039 & ,629 & (530 \\
\hline & CFO & , 001 & ,003 & ,021 & (341 & ,733 \\
\hline
\end{tabular}

a. Dependent Variable: RES_2

Lampiran 4: Hasil Uji Heteroskedastisitas Hipotesis 2

Coefficients $^{\mathrm{a}}$

\begin{tabular}{|c|c|c|c|c|c|c|}
\hline \multirow[t]{2}{*}{ Mode } & & \multicolumn{2}{|c|}{ Unstandardized Coefficients } & \multirow{2}{*}{$\begin{array}{c}\begin{array}{c}\text { Standardized } \\
\text { Coefficients }\end{array} \\
\text { Beta }\end{array}$} & \multirow[t]{2}{*}{$\mathrm{t}$} & \multirow[t]{2}{*}{ Sig. } \\
\hline & & $B$ & Std. Error & & & \\
\hline \multirow{4}{*}{1} & (Constant) &, 031 & ,006 & & 5,139 & ,000 \\
\hline & SameBig4 &,- 009 & ,006 &,- 095 & $-1,457$ & 147 \\
\hline & ROA & ,051 & ,033 & 107 & 1,549 & 123 \\
\hline & CFO & ,051 & ,033 & , 106 & 1,534 & ,126 \\
\hline
\end{tabular}

a. Dependent Variable: RES_10 
Lampiran 5: Hasil Uji Multikoleniaritas Hipotesis 1

Coefficients $^{a}$

\begin{tabular}{|c|c|c|c|c|c|c|c|c|}
\hline \multirow{2}{*}{\multicolumn{2}{|c|}{ Model }} & \multicolumn{2}{|c|}{$\begin{array}{l}\text { Unstandardized } \\
\text { Coefficients }\end{array}$} & \multirow{2}{*}{$\begin{array}{c}\text { Standardized } \\
\text { Coefficients } \\
\text { Beta } \\
\end{array}$} & \multirow[t]{2}{*}{$\mathrm{t}$} & \multirow[t]{2}{*}{ Sig. } & \multicolumn{2}{|c|}{$\begin{array}{l}\text { Collinearity } \\
\text { Statistics }\end{array}$} \\
\hline & & $B$ & Std. Error & & & & Tolerance & VIF \\
\hline \multirow{4}{*}{1} & (Constant) &,- 002 &, 000 & & $-3,723$ &, 000 & & \\
\hline & SameBig4 & ,002 & ,001 & ,011 & 2,606 &, 009 & 978 & 1,023 \\
\hline & ROA & ,923 & ,005 & 1,184 & 203,104 & ,000 & ,546 & 1,832 \\
\hline & CFO &,- 967 & ,004 & $-1,268$ & $-217,661$ & ,000 & ,546 & 1,832 \\
\hline
\end{tabular}

a. Dependent Variable: DiffTA

Lampiran 6: Hasil Uji Multikoleniaritas Hipotesis 2

Coefficients $^{\mathrm{a}}$

\begin{tabular}{|c|c|c|c|c|c|c|c|c|}
\hline \multirow[t]{2}{*}{ Mode } & & \multicolumn{2}{|c|}{$\begin{array}{l}\text { Unstandardized } \\
\text { Coefficients }\end{array}$} & \multirow{2}{*}{$\begin{array}{c}\text { Standardized } \\
\text { Coefficients } \\
\text { Beta } \\
\end{array}$} & \multirow[t]{2}{*}{$\mathrm{T}$} & \multirow[t]{2}{*}{ Sig. } & \multicolumn{2}{|c|}{ Collinearity Statistics } \\
\hline & & $B$ & Std. Error & & & & Tolerance & VIF \\
\hline \multirow{4}{*}{1} & (Constant) & ,048 &, 010 & & 4,702 & ,000 & & \\
\hline & SameBig4 &,- 005 & ,010 &,- 032 &,- 493 & 623 & ,990 - r - r & 1,010 \\
\hline & ROA &,- 036 & ,056 &,- 045 &,- 651 &, 516 & 879 & 1,137 \\
\hline & CFO & 138 & ,056 & ,170 & 2,441 & ,015 & ,872 & 1,147 \\
\hline
\end{tabular}

a. Dependent Variable: DiffTA

Lampiran 7: Hasil Uji Autokorelasi Hipotesis 1

Model Summary

\begin{tabular}{|c|c|c|c|c|c|}
\hline Model & $\mathrm{R}$ & R Square & $\begin{array}{l}\text { Adjusted R } \\
\text { Square }\end{array}$ & $\begin{array}{l}\text { Std. Error of the } \\
\text { Estimate }\end{array}$ & Durbin-Watson \\
\hline 1 &, $996^{a}$ & ,991 & ,991 &, 0069580 & 1,709 \\
\hline
\end{tabular}

a. Predictors: (Constant), CFO, SameBig4, ROA

b. Dependent Variable: DiffTA

Lampiran 8: Hasil Uji Autokorelasi Hipotesis 2

Model Summary

\begin{tabular}{|c|c|c|c|c|c|}
\hline Model & $\mathrm{R}$ & R Square & $\begin{array}{l}\text { Adjusted R } \\
\text { Square }\end{array}$ & $\begin{array}{l}\text { Std. Error of the } \\
\text { Estimate }\end{array}$ & Durbin-Watson \\
\hline 1 & $160^{\mathrm{a}}$ & ,026 & ,013 & ,0372785 & 1,985 \\
\hline
\end{tabular}

a. Predictors: (Constant), CFO, SameBig4, ROA

b. Dependent Variable: DiffTA 